\title{
FORECASTING ANORGANIC WASTE VOLUME AFTER THE IMPLEMENTATION OF PLASTIC BAG RESTRICTIONS USING DOUBLE EXPONENTIAL SMOOTHING METHOD AT BOGOR CITY
}

\author{
Ani Andriyati ${ }^{\left.a^{*}\right)}$, Embay Rohaeti ${ }^{a)}$ \\ ${ }^{a)}$ Universitas Pakuan, Bogor, Indonesia \\ Corresponding Author:ani.andriyati@unpak.ac.id
}

Article history: received 08 July 2020; revised 17 July 2020; accepted 25 August 2020

\begin{abstract}
Garbage is a classic problem causing environmental and ecosystem damage in every region, including in Bogor City. Plastic is one of the largest types of inorganic waste that causes ecosystem damage. In one day 1,7 tons of plastic waste are produced from a modern shopping center in Bogor. Several attempts were made to reduce the volume of inorganic waste. Since July 2018 the Regional Government of Bogor City has issued a regulation restricting the use of plastic bags in the modern market as an effort to reduce inorganic waste, especially plastic waste. Forecasting the volume of inorganic waste after the enactment of this regulation is needed as an evaluation step. The double exponential smoothing hole model is suitable for linear data trends. This is in accordance with the condition of inorganic waste volume data which tends to have a linear trend. Forecasting produces parameter parameter values $\alpha$ (level) 0,78 and $\gamma$ (trend) 0,09 also MAPE 7,25\%. The forecast results show that the volume of inorganic waste tends to increase in 2020. In order for this regulation to be optimal, it is necessary to consider applying these regulations not only in the modern market but also in the traditional market. In addition, it is also necessary to find an alternative to substitute for plastic so as not to switch to other inorganic types.
\end{abstract}

Keywords: inorganic; plastic; double exponential smoothing

\section{INTRODUCTION}

Garbage is a classic problem that causes environmental and ecosystem damage in every region, including the city of Bogor. The volume of waste in Bogor City in 2018 reached 663 tons per day [1], five percent of which is plastic and 1,7 tons of which are produced from modern shopping centers [2]. Plastic waste and other inorganic waste is the most difficult waste to decompose. It takes a very long time for this inorganic waste to decompose. One way to reduce inorganic waste is by recycling it into reusable items. Another effort made by the Bogor City government is to issue a regulation restricting the use of plastic bags in the modern market since July 2018. This regulation has been running for about one year and needs to be evaluated. One way to do this is by forecasting the volume of inorganic waste in the following year after the enactment of this regulation. The results of forecasting can be used for future decision making.

The forecasting method used in this research is the Exponential Smoothing method. This method is suitable for forecasting short and medium term [3]. In addition, supported by data that shows a linear trend, the linear model from Holt or Brown is appropriate so that the type of Exponential Smoothing method is Double Exponential Smoothing. Based on the comparison of various smoothing methods, it shows that the level of accuracy of the Double Exponential Smoothing method from Holt is higher than the Double Exponential Smoothing method from Brown [4] so that the Double Exponential Smoothing method from Holt is used to forecast the volume of inorganic waste in Bogor. By forecasting it can be seen the impact of limiting the use of plastic bags on the trend of inorganic waste volume in the future.

\section{RESEARCH METHODS}

This study uses an inferential method with the aim of forecasting the volume of inorganic waste after the implementation of plastic bag restriction regulations in the modern market. The data used is the volume data of inorganic waste / month in 2018 and 2019 from 24 temporary disposal sites (TPS) in Bogor City. Data analysis is divided into the three stages as follow:

a. Description of data to see the pattern of inorganic waste data. Description by plotting the data and calculating the concentration and distribution of the data

b. Forecasting

At this stage, forecasting is done using the double exponential smoothing holt. Holt's linear exponential smoothing forecast is obtained using three equations, namely:

$$
\begin{aligned}
& S^{\prime}{ }_{t}=\alpha X_{t}+(1-\alpha)\left(S^{\prime}{ }_{t-1}+t_{t-1}\right) \\
& t_{t}=\gamma\left(S^{\prime}{ }_{t}{ }^{-}{ }^{\prime}{ }_{t-1}\right)+(1-\gamma) t_{t-1} \\
& F_{t+k}=S^{\prime}{ }_{t}+t_{t} k
\end{aligned}
$$


$X_{t}=$ inorganic waste volume

$S^{\prime}{ }_{t}=$ single exponential smoothing value

$t_{t}=$ trend value in period $t$

$\alpha, \gamma=$ intermediate smoothing parameter $0-1$

$F_{t+k}=$ the forecast $k$ period to be forecast

$k=$ the number of future periods to be forecast

c. Measurement of the accuracy of the model using mean absolute deviation (MAD) and mean absolute percentage error (MAPE) [5] with formula:

$$
\begin{aligned}
& M A D=\frac{1}{k} \sum_{t=1}^{k}\left|X_{t}-F_{t}\right| \\
& M A P E=\frac{1}{k} \sum_{t=1}^{k} \frac{\left|X_{t}-F_{t}\right|}{X_{t}} \times 100 \%
\end{aligned}
$$

Data analysis stages as shown in the Figure 1.

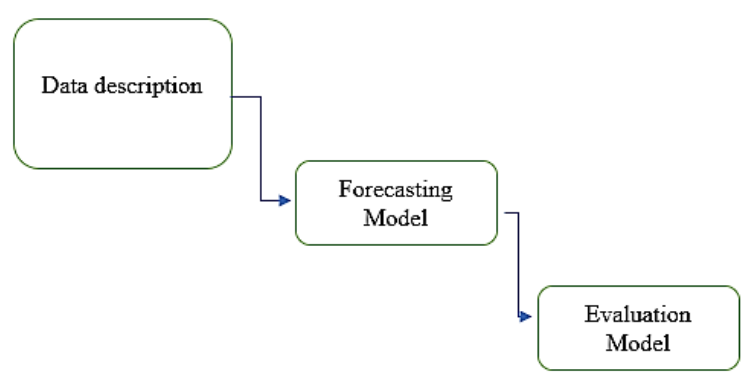

Figure 1. Stages of Data Analysis

\section{RESULTS AND DISCUSSION}

\section{Data Description}

Table 1 shows the data on the volume of inorganic waste during January 2018 to December 2019.

Table 1. volume of inorganic waste (in ton)

\begin{tabular}{rrrr}
\hline Mounth & inorganik & Mounth & inorganik \\
\hline Jan-18 & 69,60 & Jan-19 & 68,16 \\
Feb-18 & 69,57 & Feb-19 & 67,44 \\
Mar-18 & 65,78 & Mar-19 & 63,57 \\
Apr-18 & 67,04 & Apr-19 & 65,39 \\
May-18 & 75,34 & May-19 & 65,15 \\
Jun-18 & 69,34 & Jun-19 & 48,41 \\
Jul-18 & 67,14 & Jul-19 & 49,42 \\
Aug-18 & 57,74 & Aug-19 & 46,00 \\
Sep-18 & 63,09 & Sep-19 & 65,06 \\
Oct-18 & 66,61 & Oct-19 & 57,40 \\
Nov-18 & 67,70 & Nov-19 & 73,25 \\
Des-18 & 66,91 & Dec-19 & 71,70 \\
\hline
\end{tabular}

Data for the period January 2018 to June 2018 is the period before the implementation of the plastic bag restriction regulations, while the July 2018 to December 2020 period the regulations have been enacted. Figure 2 shows that from January to June 2018 the volume of inorganic waste was quite volatile. In this period the regulations have not been enforced. In the period July 2018 to May 2019 it looks more stable and in May 2019 there was a significant decline. This shows that the regulation only has an impact on reducing the volume of inorganic waste after one year. However, in September 2019 it again showed an upward linear trend.

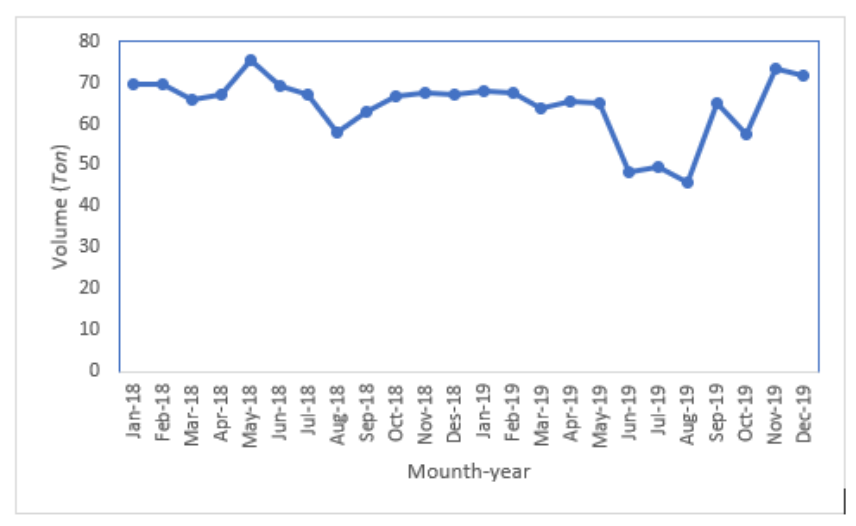

Figure 2. Plot of Inorganic Waste Volume

Table 2 shows the descriptive value of the data in the period before and after the enactment of the regulation. The average volume of inorganic waste in the period after the enactment of the regulation is lower than before the enactment of the regulation. The average volume per month reached 62.79 tons. This shows a decrease of 7 tonnes compared to the average period before the enactment of the regulation. However, the whole waste increases the average volume increase.

Table 2. Descriptive Data

\begin{tabular}{lrrrrr}
\hline & N & Min & Max & Mean & Std. Dev \\
\hline Inorganic_before & 6 & 65,78 & 75,34 & 69,45 & 3,29 \\
Inorganic_after & 18 & 46,00 & 73,25 & 62,79 & 7,87 \\
Whole_before & 6 & 420,12 & 435,14 & 427,73 & 5,97 \\
Whole_after & 18 & 414,99 & 541,83 & 459,21 & 31,19
\end{tabular}

\section{Forecasting and Evaluation Model}

The model used for this study is Holt's double exponential smoothing. This model was taken with consideration of the suitability of the data plots and data availability. The calculation is carried out with the help of minitab 17.

Trials and errors in the combination of numbers $0-1$ were carried out to determine the best $\alpha$ (alpha) and $\gamma$ (gamma) parameters to be used in forecasting the volume of inorganic waste in 2020. Based on trial and error, the 
parameter values obtained were $\alpha$ (level) 0,78 and $\gamma$ (trend) 0,09 . The forecasting model is obtained in formula 8

$$
\begin{gathered}
S_{t}^{\prime}=0,78 X_{t}+0,22\left(S_{t-1}^{\prime}+t_{t-1}\right) \\
t_{t}=0,09\left(S^{\prime}{ }_{t} S^{\prime}{ }_{t-1}\right)+0,91 t_{t-1} \\
F_{t+k}=0,78 X_{t}+0,22\left(S^{\prime}{ }_{t-1}+t_{t-1}\right)+ \\
0,09\left(S^{\prime}{ }_{t}-S_{t-1}^{\prime}\right)+0,91 t_{t-1}
\end{gathered}
$$

The value of the single exponential smoothing $\left(S^{\prime}{ }_{t}\right)$, the value of the trend in the $t$ period $\left(t_{t}\right)$ and the value of the forecasting component are shown in Table 3.

Table 3. Test Values

\begin{tabular}{rrlllr}
\hline Mounth & Inorganic & $\boldsymbol{S}_{\boldsymbol{t}}{ }_{\boldsymbol{t}}$ & \multicolumn{1}{l}{$\boldsymbol{t}_{\boldsymbol{t}}$} & \multicolumn{1}{l}{ Fits } & Residual \\
\hline Jan-18 & 69,60 & 69,80 & $-2,28$ & 70,53 & $-0,92$ \\
Feb-18 & 69,57 & 69,12 & $-1,15$ & 67,52 & 2,04 \\
Mar-18 & 65,78 & 66,26 & $-1,47$ & 67,97 & $-2,19$ \\
Apr-18 & 67,04 & 66,55 & $-1,30$ & 64,79 & 2,25 \\
May-18 & 75,34 & 73,12 & $-0,56$ & 65,24 & 10,10 \\
Jun-18 & 69,34 & 70,05 & $-0,80$ & 72,55 & $-3,21$ \\
Jul-18 & 67,14 & 67,61 & $-0,95$ & 69,25 & $-2,10$ \\
Aug-18 & 57,74 & 59,70 & $-1,61$ & 66,65 & $-8,91$ \\
Sep-18 & 63,09 & 61,99 & $-1,24$ & 58,09 & 5,00 \\
Oct-18 & 66,61 & 65,32 & $-0,81$ & 60,75 & 5,85 \\
Nov-18 & 67,70 & 67,00 & $-0,58$ & 64,51 & 3,20 \\
Des-18 & 66,91 & 66,81 & $-0,54$ & 66,42 & 0,49 \\
Jan-19 & 68,16 & 67,74 & $-0,40$ & 66,26 & 1,90 \\
Feb-19 & 67,44 & 67,42 & $-0,39$ & 67,34 & 0,10 \\
Mar-19 & 63,57 & 64,33 & $-0,65$ & 67,03 & $-3,45$ \\
Apr-19 & 65,39 & 65,02 & $-0,52$ & 63,68 & 1,71 \\
May-19 & 65,15 & 65,01 & $-0,47$ & 64,49 & 0,66 \\
Jun-19 & 48,41 & 51,96 & $-1,66$ & 64,53 & $-16,12$ \\
Jul-19 & 49,42 & 49,62 & $-1,72$ & 50,30 & $-0,88$ \\
Aug-19 & 46,00 & 46,42 & $-1,86$ & 47,89 & $-1,89$ \\
Sep-19 & 65,06 & 60,55 & $-0,36$ & 44,56 & 20,50 \\
Oct-19 & 57,40 & 58,01 & $-0,56$ & 60,19 & $-2,80$ \\
Nov-19 & 73,25 & 69,77 & 0,60 & 57,45 & 15,80 \\
Dec-19 & 71,70 & 71,40 & 0,69 & 70,37 & 1,33 \\
\hline & & & & &
\end{tabular}

The resulting forecast model is quite good with a MAPE (Mean Absolute Percentage Errors) value of 7,25\%, Mean Absolute Deviation (MAD) of 4,73. This model can be used to forecast the volume of inorganic waste in 2020 as shown in Table 3 and Figure 3.

In Figure 3, the blue dots represent the actual values, the blue dots represent the fits value and the green dots represent the forecast value. The plot shows that the fits value is close to the actual value, which means that the model used is correct. The forecast value shows an upward trend, so it can be said that in 2020 the volume of inorganic waste in 2020 will increase at intervals of 72 to 79 tons / month.
Table 4. Forecasting the Volume of Inorganic Waste in 2020

\begin{tabular}{rr}
\hline \multicolumn{1}{l}{ Mounth } & \multicolumn{1}{l}{ Forecast } \\
\hline Jan-20 & 72,10 \\
Feb-20 & 72,79 \\
Mar-20 & 73,49 \\
Apr-20 & 74,18 \\
May-20 & 74,87 \\
Jun-20 & 75,57 \\
Jul-20 & 76,26 \\
Aug-20 & 76,96 \\
Sep-20 & 77,65 \\
Oct-20 & 78,34 \\
Nov-20 & 79,04 \\
Dec-20 & 79,73 \\
\hline
\end{tabular}

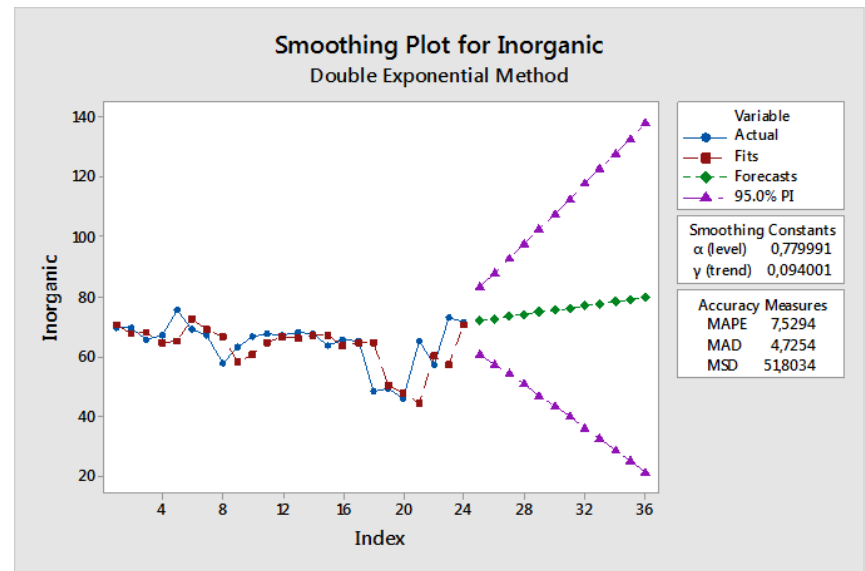

Figure 3. Plot of Actual Value, Fits and Forecasting

\section{CONCLUSION}

The regulations on limiting the use of plastic bags that are implemented in the modern market are not sufficient to reduce the overall volume of inorganic waste. When these regulations are implemented in the modern market, it is predicted that there will be an upward trend in the volume of inorganic waste. In order for this regulation to be optimal, it is necessary to consider applying the regulation not only in the modern market but also in the traditional market. In addition, it is necessary to further investigate whether the alternative substitute for plastic bags comes from other inorganic types so that it is predicted that the inorganic waste tends to increase.

\section{REFERENCES}

[1] BPS, "Bogor Dalam Angka 2019”, BPS Kota Bogor, 2019. 
[2] Alif, "Resmi Diberlakukannya, Tidak Ada Lagi Kantong Plastik di Retail Modern Kota Bogor", Berita Kota Bogor, 2018.

Available:https://kotabogor.go.id/index.php/show_post /detail/11117

[3] Makridakis, S, Wheelwright, Steven C.,McGee, V.E, "Metode dan Aplikasi Peramalan Jilid 1", Jakarta: Erlangga, 1999.

[4] R. Ariyanto, D. Puspitasari, F Ericawati, "Penerapan Metode Double Exponential Smoothing Pada Peramalan Produksi Tanaman Pangan", Jurnal Informatika Polinema, vol. 4, no.1, pp. 58-62, 2017.

[5] M.D.W. Siahaan, N. Kaherani, "Peramalan Tingkat Sampah Plastik Yang Akan Di Daur Ulang Dengan Metode Double Exponential Smoothing Dari Brown", Jurnal Karismatika, vol. 2, no.1, pp. 88-98, 2016. 